\title{
QUARTZ ACCELERATOR OF CHARGED PARTICLES
}

\author{
O.O. Ivashchuk, A.V.Shchagin ${ }^{1,2}$, A.S. Kubankin ${ }^{1,3}$, I.S. Nikulin ${ }^{1}$, V.S. Miroshnik, \\ V.I. Volkov ${ }^{2}$, V.Y. Ionidi ${ }^{4}$, A.S. Chepurnov ${ }^{4}$, A.N. Oleinik ${ }^{1,5}$, D.A. Lepeshko ${ }^{6}$, M.A. Zhukova ${ }^{1}$ \\ ${ }^{1}$ Belgorod State National Research University, Belgorod, Russia; \\ ${ }^{2}$ National Science Center “Kharkov Institute of Physics and Technology”, Kharkiv, Ukraine; \\ ${ }^{3}$ Lebedev Physical Institute, Moscow, Russia; \\ ${ }^{4}$ Skobeltsyn Institute of Nuclear Physics, Moscow, Russia; \\ ${ }^{5}$ John Adams Institute at Royal Holloway, University of London, Egham, UK; \\ ${ }^{6}$ Joint Stock Company "Scientific Research Institute of Vacuum Technology" \\ named after S.A. Vekshinsky, Moscow, Russia \\ E-mail: ooleg.ivashuk@gmail.com
}

Results of first experiments with piezoelectric accelerator built on quartz crystals as piezoelectric elements are presented. Accelerating voltage in such quartz accelerator is produced at compression in vacuum of quartz crystals along polar axis. The construction of the quartz accelerator and results of measurements the spectra of X-ray radiation which is produced by electrons accelerated in such accelerator are described. Accelerating voltage in quartz accelerator observed in the experiment is discussed.

PACS: 29.17.+w

\section{INTRODUCTION}

In recent times, a few methods of acceleration of charged particles and production of X-rays of energy up to tens kiloelectronvolt in miniature accelerators without outer source of accelerating voltage were developed. For example, X-ray radiation is produced by electrons accelerated in the electric field arising in vacuum due to pyroelectric [1 - 3] and triboelectric [4] effects or in the high-frequency field which is generated by a piezoelectric transformer in vacuum [5 - 7]. More recently, the concept of piezoelectric accelerator operating at compression of piezoelectrics in vacuum was proposed and confirmed experimentally with use of piezoelectric ceramics as piezoelectric elements [8]. Here we describe our fist experiments concerned to application of the most popular piezoelectricsuch as quartz crystal as piezoelectric elements in piezoelectric accelerator and generator of X-rays.

\section{EXPERIMENT}

Experiments have been performed in Belgorod National Research University. The experimental setup is presented in Fig. 1.

The cylindrical assembly of two piezoelectric quartz cylinders of diameter $20 \mathrm{~mm}$ and high $10 \mathrm{~mm}$ with cupper high-voltage electrode is installed between copper grounded disks of diameter $50 \mathrm{~mm}$ in the vacuum chamber. The polar axis of the quartz crystals is aligned along the cylinder's axis. The copper high-voltage electrode of height $5 \mathrm{~mm}$ with the maximum diameter $30 \mathrm{~mm}$ and the diameter of both bases $20 \mathrm{~mm}$ is located between two piezoelectric quartz cylinders. The compression of the assembly of two piezoelectric quartz cylinders and high-voltage electrode was provided by the controlled force $\vec{F}$ from the testing machine Instron 336 through the metal cylinders. The metal cylinders passed the force from the testing machine inward the vacuum chamber.

The spectra of the X-ray radiation were measured by the X-ray spectrometer consisting of the semiconductor X-ray detector Amptek CdTe 123 and digital pulse processor PX-5.

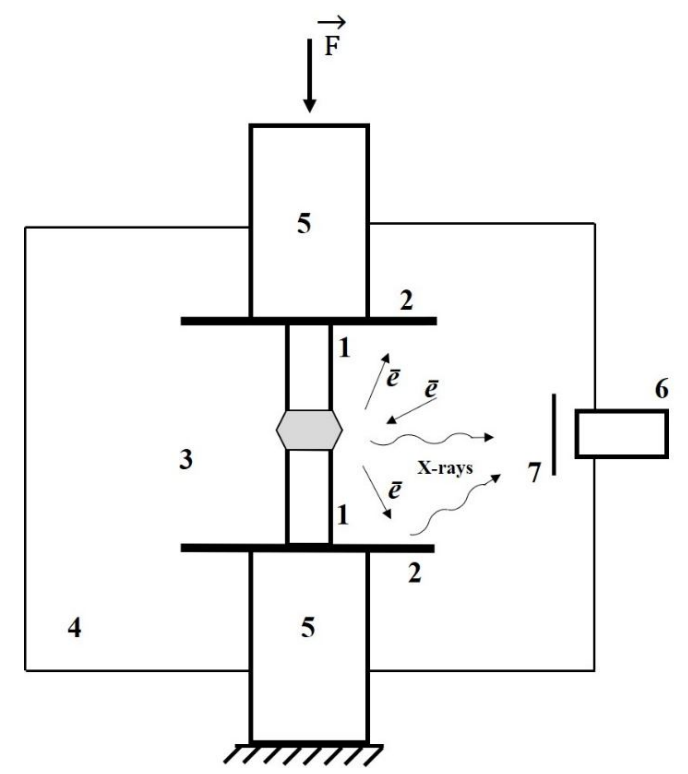

Fig. 1. The experimental setup.

1 - cylindrical assembly of two piezoelectric quartz cylinders; 2 - copper grounded disks; 3 - copper high-voltage electrode; 4 - vacuum chamber; 5 - metal cylinders of the testing machine Instron 336; 6 -semiconductor X-ray detector; 7 - maylar foil installed in front of the entrance window of the detector

The peaking time of spectrometer was $3.2 \mu \mathrm{s}$ in the experiment. Energy calibration of the spectrometer was performed using X-ray lines of ${ }^{237} \mathrm{~Np}$ source. The entrance window of the detector was inserted into the vacuum chamber and detector could register radiation from high-voltage electrode and both cupper grounded plates. The $100 \mu \mathrm{m}$ mylar foil was installed at the entrance window of the detector to defend $100 \mu \mathrm{m}$ thick Be entrance foil of the detector at possible crash of the quartz cylinders at compression.

Both spectra were measured at the pressure of the residual gas in vacuum chamber $10^{-6}$ Torr and at maximum mechanical strength in the quartz $300 \mathrm{MPa}$.

The spectrum of the X-ray radiation measured at the compression the assembly in the case of production of 
the positive potential at the high-voltage electrode is presented in Fig. 2,a. The spectrum was measured during $30 \mathrm{~s}$ compression from zero strength up to value 300 $\mathrm{MPa}$ and also for 415 seconds after fixing of the strength. Electrons accelerated from the residual gas toward the high-voltage electrode and produced X-rays at hitting it. The spectrum contains twospectral peaks of the characteristic X-rays on the background of the bremsstrahlung. The spectral peaks of characteristic Xrays with the energies 8.04 and $8.9 \mathrm{keV}$ correspond to $\mathrm{K}_{\alpha}$ and $\mathrm{K}_{\beta}$ lines of the $\mathrm{Cu}$ atom composing the highvoltage electrode. The maximum energy of the bremsstrahlung is about $30 \mathrm{keV}$. Total number of registered quanta is 287106 counts for $445 \mathrm{~s}$.
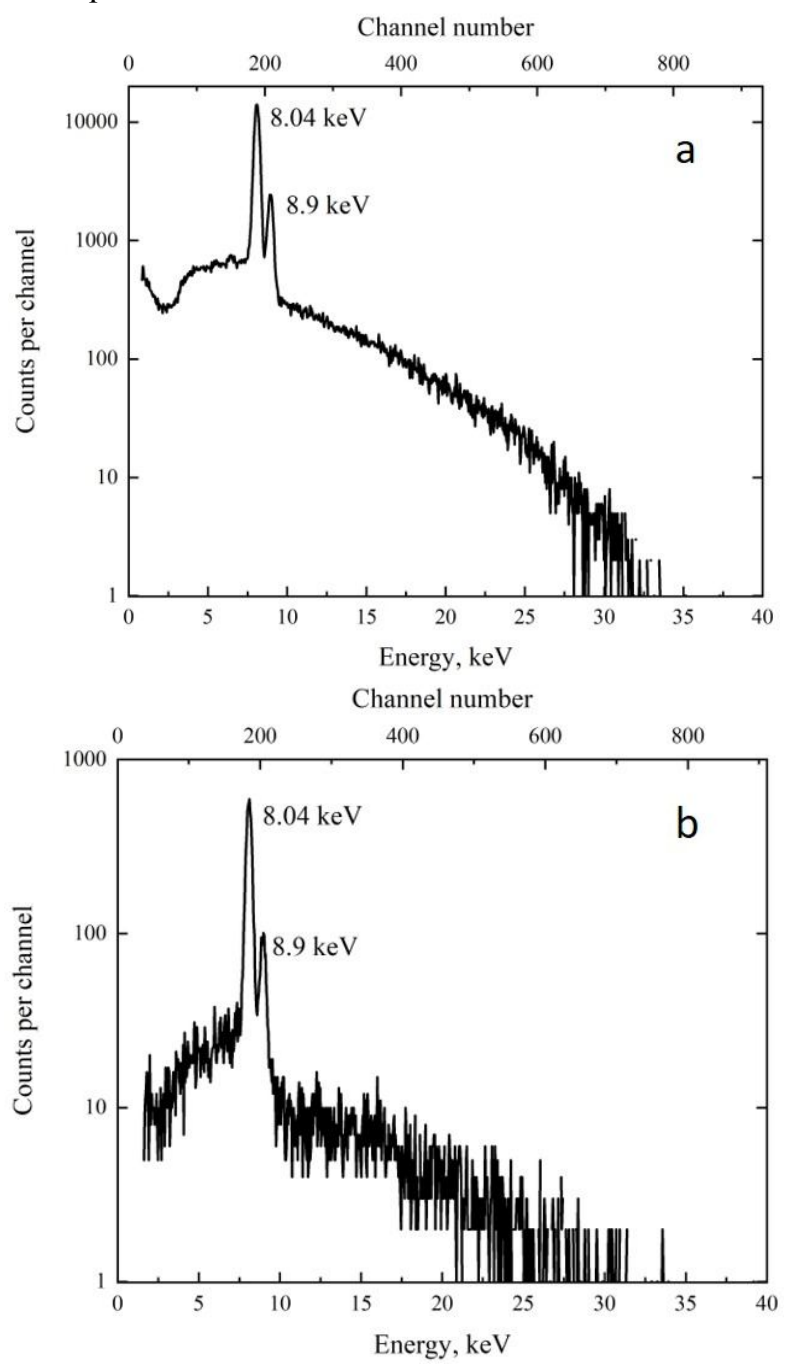

Fig. 2. The spectra of $X$-ray radiation measured at the positive (a) negative (b) potential at the high-voltage electrode

The chamber was opened and both quartz crystals were turned over before the measurement of the second spectrum. In this case negative potential was produced at high-voltage electrode at compression. Electrons from the area around of the high-voltage electrode accelerated toward grounded cupper plates and produced X-rays hitting it. The measured spectrum is shown in Fig. 2,b. It was measured during $30 \mathrm{~s}$ compression from zero strength up to value $300 \mathrm{MPa}$ and also for $176 \mathrm{~s}$ after fixing of the strength and radiation cessation. The spectrum is similar to the first one but intensity of radiation is lower. The maximum energy of the bremsstrahlung of about $30 \mathrm{keV}$ is the same. Total number of registered quanta is 7488 counts for $206 \mathrm{~s}$.

\section{DISCUSSION}

Described here experiment demonstrated the possibility for application of quartz crystals in piezoelectric accelerator and X-ray generator. The maximum accelerating voltage defines the maximum energy of accelerated electrons that can be estimated as maximum energy in the bremsstrahlung X-ray spectra. Obtained in present experiment accelerating voltage $30 \mathrm{kV}$ is in two times less than one observed in [8] with use of ceramics piezoelectrics. The reason of the moderate value of observed accelerating voltage may be in current leakage from the high-voltage electrode, and/or in influence of mounting capacitance that is between the high voltage electrode and ground, and/or in nonlinearity of the piezoelectric module.

\section{ACKNOWLEDGEMENTS}

The work was financially supported by a Program of the Ministry of Education and Science of the Russian Federation for higher education establishments, (project № 3.1631.2017/4.6).

\section{REFERENCES}

1. J.D. Brownridge. Pyroelectric X-ray generator // Nature. 1992, v. 358, p. 287-288.

2. J.D. Brownridge, S.M. Shafroth. Electron and positive ion beams and X-rays produced by heated and cooled pyroelectric crystals such as $\mathrm{LiNbO}_{3}$ and Li$\mathrm{TaO}_{3}$ in dilute gases: phenomenology and applications // Trends in Lasers and Electro-Optics Research / Ed. W.T. Arkin. Nova Science, New York, 2004, Chapter 2, p. 59-95.

3. A.V. Shchagin, V.S. Miroshnik, V.I. Volkov, A.N. Oleinik. Ferroelectric ceramics in a pyroelectric accelerator // Appl. Phys. Lett. 2015, v. 107, p. 233505.

4. J.R. Hird, C.G. Camara, S.J. Putterman. A triboelectric X-ray source // Appl. Phys. Lett. 2011, v. 98, p. 133501.

5. B. Gall, S.D. Kovaleski, J.A. Van Gordon, P. Norgard, A. Benwell, B.H. Kim, J.W. Kwon, G.E. Dale. Investigation of the piezoelectric effect as a means to generate X-rays // IEEE Transactions on Plasma Science. 2013, v. 41, p. 106-111.

6. A.V. Shchagin, V.S. Miroshnik, V.I. Volkov, A.S. Kubankin, O.O. Ivashchuk. Piezoelectric transformer aided X-ray generation in vacuum // Glass and Ceramics. 2018, v. 74, p. 404-405.

7. A.V. Shchagin, V.S. Miroshnik, V.I. Volkov, A.S. Kubankin, O.O. Ivashchuk. Ceramic piezoelectric transformer in vacuum for acceleration of electrons and production of X-rays // Materials MDPI. 2018, v. 11, p. 1188.

8. O.O. Ivashchuk, A.V. Shchagin, A.S. Kubankin, I.S. Nikulin, A.N. Oleinik, V.S. Miroshnik, V.I. Volkov. Piezoelectric Accelerator // Scientific Reports. 2018, v. 8, p. 16488.

Article received 14.01.2020 


\section{КВАРЦЕВЫЙ УСКОРИТЕЛЬ ЗАРЯЖЕННЫХ ЧАСТИЦ}

О.О. Иващук, А.В. Щагин, А.С. Кубанкин, И.С. Никулин, В.С. Мирошник, В.И. Волков, В.Ю. Иониди, А.С. Чепурнов, А.Н. Олейник, Д.А. Лепешко, М.А. Жукова

Представлены результаты первых экспериментов с пьезоэлектрическим ускорителем, построенным на кристаллах кварца в качестве пьезоэлементов. Ускоряющее напряжение в таком кварцевом ускорителе создается при сжатии в вакууме кристаллов кварца вдоль полярной оси. Описаны конструкция кварцевого ускорителя и результаты измерений спектров рентгеновского излучения, которое производится электронами, ускоренными в таком ускорителе. Обсуждается ускоряющее напряжение в кварцевом ускорителе, наблюдаемое в эксперименте.

\section{КВАРЦОВИЙ ПРИСКОРЮВАЧ ЗАРЯДЖЕНИХ ЧАСТИНОК}

\section{О.О. Іващук, А.В. Щагін, А.С. Кубанкін, І.С. Нікулін, В.С. Мірошник, В.І. Волков, В.Ю. Іоніді,} А.С. Чепурнов, А.Н. Олейник, Д.А. Лепешко, М.А. Жукова

Представлено результати перших експериментів 3 п'єзоелектричним прискорювачем, побудованим на кристалах кварцу в якості п'єзоелементів. Прискорювальна напруга в такому кварцовому прискорювачі створюється при стисненні у вакуумі кристалів кварцу уздовж полярної осі. Описані конструкція кварцового прискорювача і результати вимірювань спектрів рентгенівського випромінювання, яке виробляється електронами, прискореними в такому прискорювачі. Обговорюється прискорююча напруга в кварцовому прискорювачі, що спостерігається в експерименті. 